\title{
Spot Ages
}
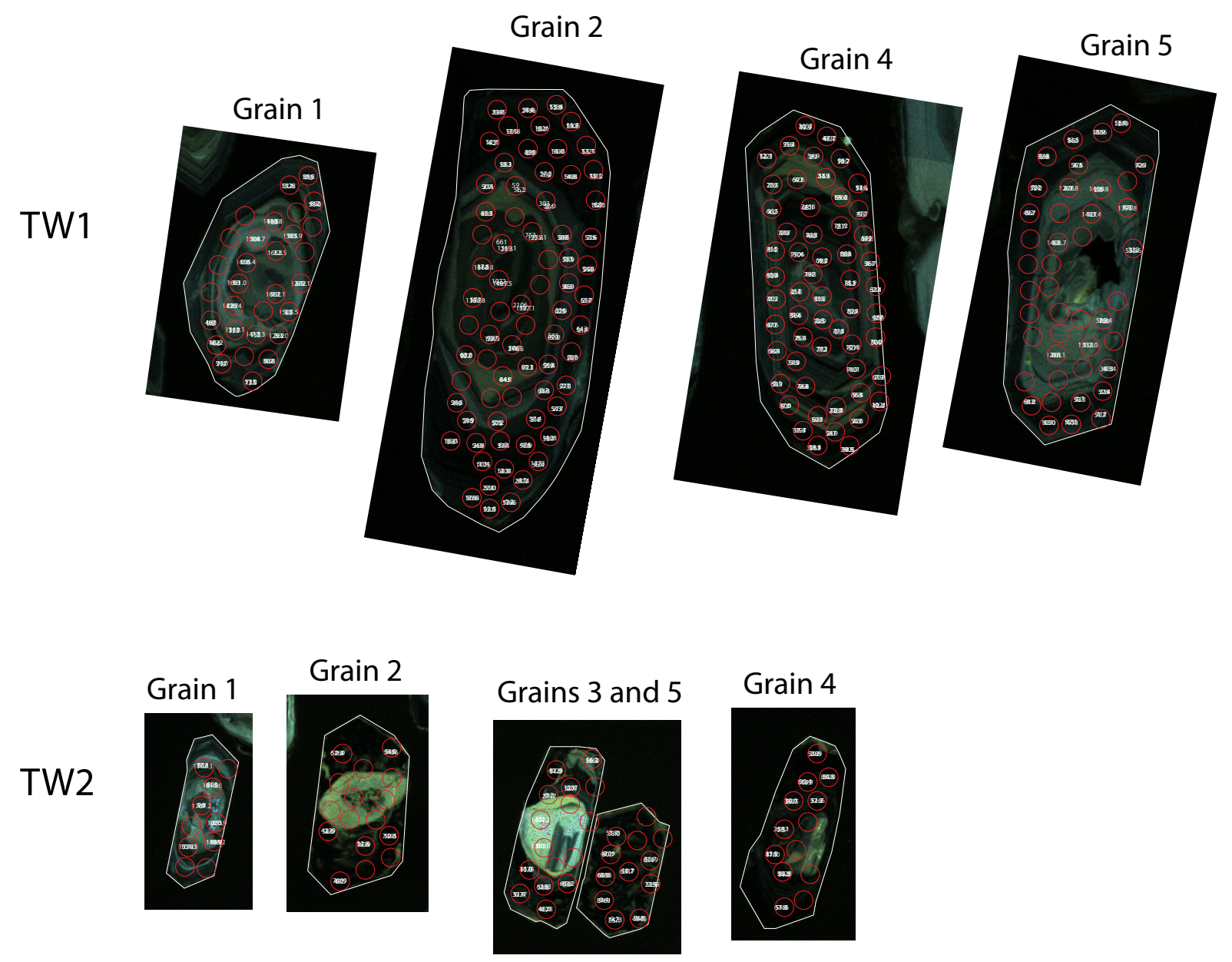

Grain 2
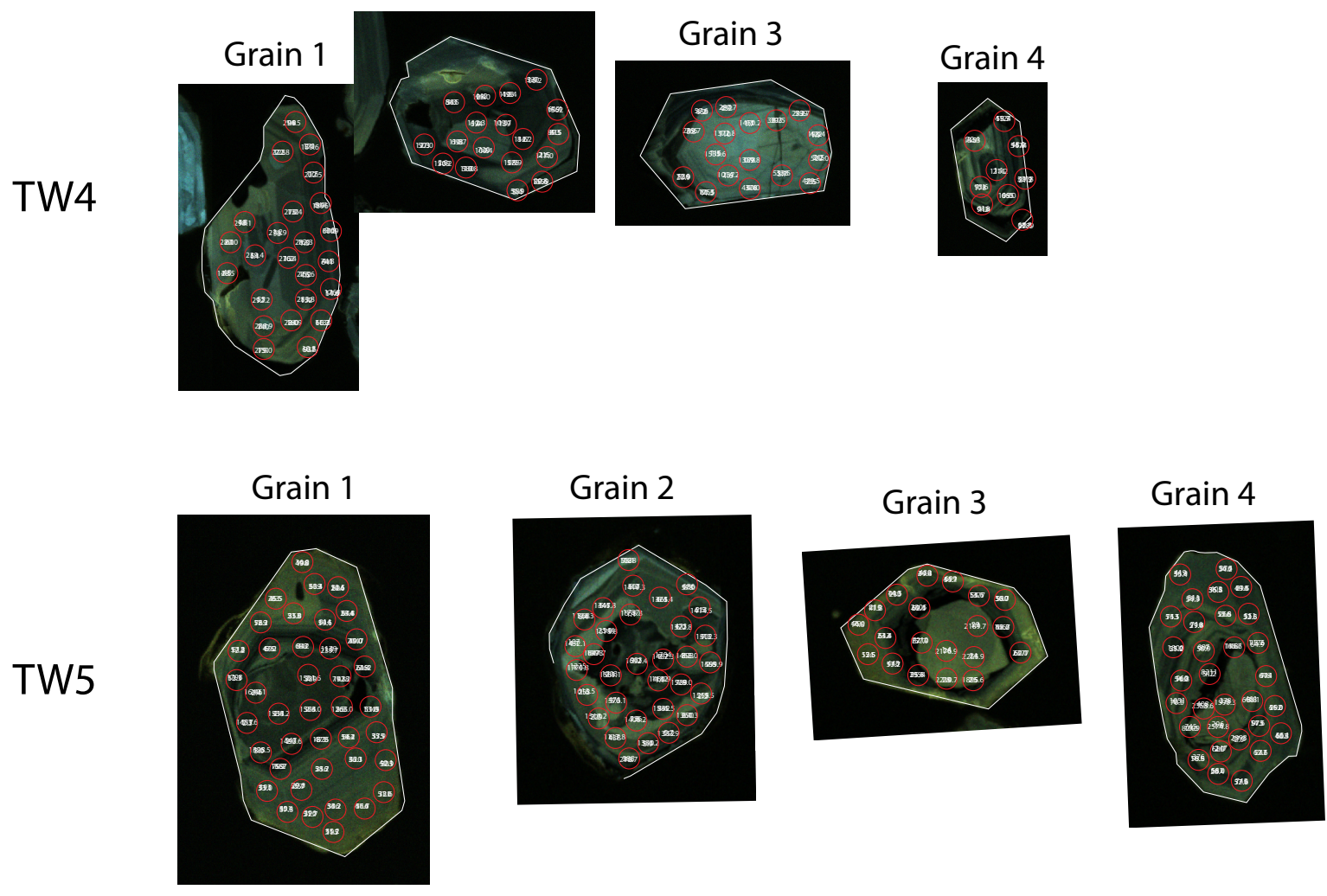

Grain 5

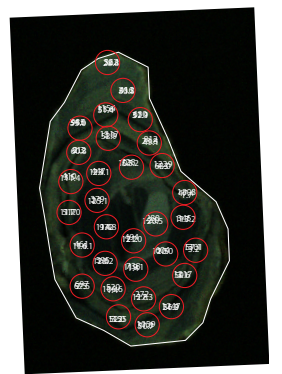

